\title{
Influence of cinnamic acid on lymphocyte proliferation, cytokine release and Klebsiella infection in mice
}

\author{
N Ivanovska 1, H Neychev 1, Z Stefanova 1, \\ V Bankova ${ }^{2}$, S Popov ${ }^{2}$ \\ ${ }^{1}$ Bulgarian Academy of Sciences, Institute of Microbiology; \\ 2 Bulgarian Academy of Sciences, Institute of Organic Chemistry, \\ 26, G Bonchev St, 1113 Sofia, Bulgaria
}

(Received 17 February 1994; accepted 16 November 1994)

\begin{abstract}
Summary - The effect of a complex of propolis constituents, cinnamic acid and L-lysine, on host defence mechanisms was investigated. After intraperitoneal (ip) application of cinnamic acid lysine complex (CN•Ly) to mice at a dose of $3 \mathrm{mg} / \mathrm{kg}$ for 3 consecutive days prior to inoculation with Klebsiella pneumoniae, a protective effect was observed. The action of CN-Ly was associated with its ability to provoke proliferation of thymic and splenic lymphocytes and to augment mitogen-induced proliferation, and the release of interleukin-1 (IL-1) and interleukin-2 (IL-2). In all experiments, a solution of L-lysine in a concentration equivalent to the lysine content in the complex was used for comparison. The results indicated that free lysine acted in a mitogen-like manner predominantly on T-lymphocytes. In the complex, lysine played the role of a carrier and exhibited a less pronounced effect.
\end{abstract}

propolis / cinnamic acid / cytokine release / Klebsiella infection

\section{INTRODUCTION}

Propolis is a natural substance with a very complex chemical composition, including benzoic acid and esters, substituted phenolic acid and esters, terpenoids, flavonoid aglycones etc (Bankova et al, 1987; Walker and Crane, 1987; Greenaway et al, 1991). Although contemporary chemical methods permit determination of propolis constituents, its content cannot be readily standardized. There is a great need for the active compo- nents to be determined and a product with a constant composition to be synthesized. In previous investigations we have used a fraction from natural propolis, obtained after separation of waxes, saccharides and amino acids. It is enriched in phenolic and flavonoid compounds and additionally combined with L-lysine to gain water solubility. This product, the water-soluble derivative (WSD), was found to cause activation of macrophages and lymphocytes, and induction of some cytokines, such as interleukin-1 and tumor 
necrosis factor (Dimov et al, 1991; Dimov et al, 1992). Furthermore, to determine its active principles some of the individual WSD constituents were combined with L-lysine and the effect of such lysine complexes on immune mechanisms was tested. Cinnamic acid is one of the natural propolis constituents and can be regarded as a parent molecule of the other phenolics. The complex of cinnamic acid with L-lysine (CN-Ly) was observed to alter the overall complement activity and the functionl activity of $\mathrm{C}_{3}$ complement component when it was applied to mice and also to enhance the antibody response (lvanovska et al, 1993). The purpose of the present work was to extend previous studies on the mechanism of action of the lysine complex in vivo and in vitro. In this study we investigated the protective effect of CN•Ly in Klebsiella pneumoniae infection in mice and its influence on lymphocyte proliferation, interleukine-1 (IL-1) and interleukine-2 (IL-2) release.

\section{MATERIALS AND METHODS}

\section{Cinnamic acid lysine complex}

Cinnamic acid (Fluka, Switzerland) was combined with L-lysine (Fluka) at a molar ratio 1:2 as described previously (Ivanovska et al, 1993). The complex was evaporated under vacuum and solutions in saline were made extempore.

\section{Treatment}

Female mice, strain ICR, 6-8 weeks of age, $18-20 \mathrm{~g}$ body weight were used. The dose for the lysine treatment was chosen to be approximately equal to the lysine content in the complex, according to their molar ratio 1:2. The $C N \cdot L y$ and Ly were infected interperitoneally (ip) in a volume of $0.2 \mathrm{ml}$. Control animals received $0.2 \mathrm{ml}$ saline ip. Sera, splenocytes and peritoneal macrophages ( $\mathrm{pMo}$ ) were pooled for the in vitro determinations $24 \mathrm{~h}$ after the last treatment.

\section{Bacterial infection}

$K$ pneumoniae, strain 52145 (Institute Pasteur, Paris) was grown overnight in Trypticase soy broth (Difco, USA). Mice were inoculated sc with 25-30 live cells $\left(L_{50}\right) 24 \mathrm{~h}$ after the last treatment with the substances. The survival of the infected animals was monitored up to the 8th day.

\section{Proliferative assay}

Pooled splenocytes, obtained $24 \mathrm{~h}$ after the last treatment of animals, were suspended in RPMI1640 medium (Sigma Chem Co, USA) and separated by density centrifugation on Lymphoprep (Nygeaar, Oslo, Norway). After 2 washings lymphocytes were resuspended at triplicate in RPMI medium, supplemented with $10 \%$ FCS, $20 \mathrm{mM}$ HEPES, $100 \mathrm{U} / \mathrm{ml}$ penicillin and $0.1 \mathrm{mg}$ streptomycin (Flow Lab, UK) and $2.5 \times 10^{-5} \mathrm{M}$ 2-mercaptoethanol (Merck, Germany) and cultivated in a 96-well U-bottom plate (Nunc, Denmark) at a final concentration of $2 \times 10^{5}$ cells/well. The mitogens were added to a final concentration of $2 \mu \mathrm{g} / \mathrm{ml}$ for phytohemagglutinin (PHA; Sigma, Saint Louis, Ml, USA) and $5 \mu \mathrm{g} / \mathrm{ml}$ for lipopolysaccharide (LPS) and concanavalin A (ConA, Difco Labs, Detroit, MI, USA).

For in vitro treatment $C N \cdot L y$ and $L y$ were added at a concentration of 10 or $20 \mu \mathrm{g} / \mathrm{ml}$, which is relevant to an in vivo dose of $3 \mathrm{mg} / \mathrm{kg}$. Cells were pulsed for the last $24 \mathrm{~h}$ of cultivation with $0.5 \mu \mathrm{Ci} /$ well tritiated thymidine $\left(\left[{ }^{3} \mathrm{H}\right] \mathrm{TdR}\right.$; Amersham, UK).

\section{IL-1 activity assay}

The level of IL- 1 in serum from treated animals or in $24 \mathrm{~h}$ supernatants from peritoneal macrophages treated in vitro with substances was determined by [ $\left.{ }^{3} \mathrm{H}\right] \mathrm{TdR}$ assay (Meltzer and Oppenheim, 1977). Single cell suspensions of thymuses from ICR mice $\left(1.0 \times 10^{6}\right.$ cells in $0.1 \mathrm{ml})$ were cultured with $0.1 \mathrm{ml}$ serum $(1: 100$ diluted) or $0.1 \mathrm{ml}$ of macrophage supernatant (1:4 diluted) for $48 \mathrm{~h}$. The culture medium contained a submitogenic concentration of PHA (1 $\mu \mathrm{g} / \mathrm{ml})$ and $2.5 \times 10^{-5} 2$-mercaptoethanol. Thymic cultures were pulsed for $6 \mathrm{~h}$ with $0.5 \mu \mathrm{Ci} /$ well of $\left[{ }^{3} \mathrm{H}\right] \mathrm{TdR}$. 


\section{IL-2 assay}

Splenocytes from pretreated with CN•Ly or Ly animals were cultivated at a concentration of $1 \mathrm{x}$ $10^{7} \mathrm{cells} /$ well in the presence or absence of antigen (sheep red blood cells, SRBC, $5 \times 10^{6}$ cells/well) in 24-F bottom plate (Falcon ${ }^{\circledR}$, Becton-Dickinson, USA). Supernatants were collected at different intervals and IL-2 secretion was measured by determining the growth of the murine IL-2 dependent T-lymphocyte cell line CTLL-2 (Gillis et al, 1978). The CTLL-2 cells were cultured in 96-well F-bottom microplate at $5 \times 10^{3}$ in $0.2 \mathrm{ml}$ of RPMI-1640 medium, supplemented with $10 \% \mathrm{FCS}$, containing serial dilutions of culture supernatants to be tested for IL-2 activity. After $18 \mathrm{~h}$ cells were pulsed with $1.0 \mu \mathrm{Ci}$ of $\left[{ }^{3} \mathrm{H}\right]$ $\mathrm{TdR}$ and cultured for additional $16 \mathrm{~h}$. Recombinant IL-2 (Bachem AG, Switzerland) at a concentration of $25 \mathrm{U} / \mathrm{ml}$ was used as a positive control.

\section{RESULTS}

\section{Effect in Klebsiella pneumoniae infection}

The course of infection was improved after the 3 daily ip applications of $C N \cdot L y$
(3 $\mathrm{mg} / \mathrm{kg} / \mathrm{d}$ ) prior to inoculation. The number of the survivals and the mean survival time were significantly elevated (table I). A dose of $6 \mathrm{mg} / \mathrm{kg}$ did not show a greater effect and the highest dose of $10 \mathrm{mg} / \mathrm{kg}$ was without protective action. The injection of Ly in a dose of 2 and $4 \mathrm{mg} / \mathrm{kg} /$ daily aggravated the effect of infection and the MST was reduced (table I). A toxic effect was not indicated since the substances were injected to intact mice in the same doses and no mortality was detected (data not shown).

\section{Proliferative response of splenocytes}

Splenocyte cells from mice treated with $\mathrm{CN}-\mathrm{Ly}$ or Ly possessed enhanced ability to incorporate $\left[{ }^{3} \mathrm{H}\right] \mathrm{TdR}$ in the presence of mitogenic concentrations of LPS, PHA or ConA. The effect of CN-Ly was greater in the case of LPS in comparison to Ly and the opposite situation was observed in the case of PHA and ConA. A proliferative tendency was detected in the splenocyte cultures from treated animals in the absence of mitogen (fig 1).

Table I. Effect of CN•Ly and Ly on K pneumoniae infection in mice.

Substancea

Dose $(m g / k g / d)$
No of mice in group/

No of survivors
$M S T$ b

(d)

4.8

8.0

6.7

4.0

$20 / 4$

3.3

None

$20 / 10$

5.1

a The CN-Ly or Ly were administered in an indicated dose ip on days $-3,-2$ and -1 before inoculation with $K$ pneumoniae. ${ }^{b}$ MST: mean survival time. Data were similar in 2 independent experiments and $P<0.05$, as calculated to the control by $\chi^{2}$ method 


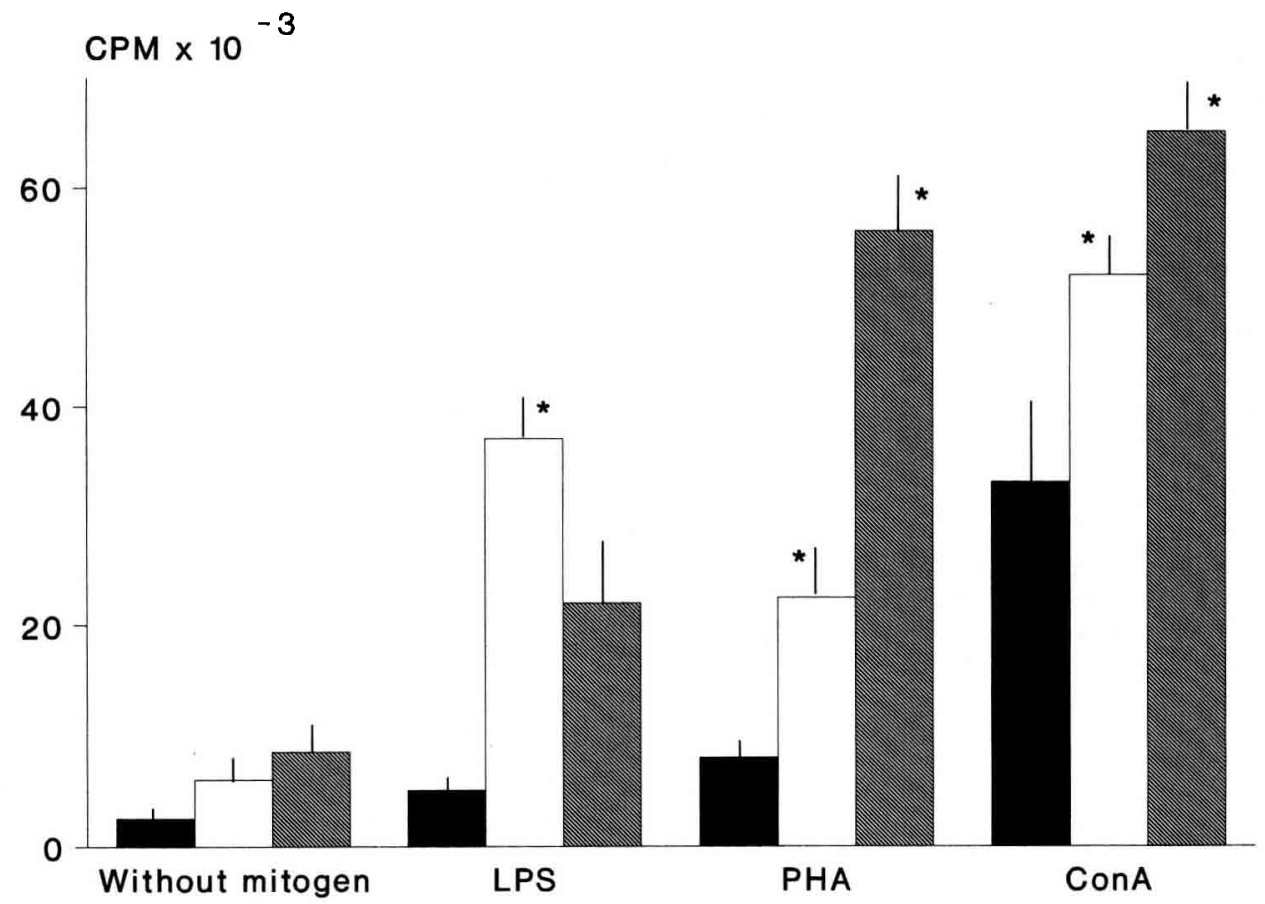

Fig 1. Proliferation of splenic lymphocytes from pretreated with CN-Ly (white) or Ly (gray) mice in the absence of mitogen or in the presence of LPS $(5 \mu \mathrm{g} / \mathrm{ml})$, PHA $(2 \mu \mathrm{g} / \mathrm{ml})$ and ConA $(5 \mu \mathrm{g} / \mathrm{ml})$. Black: control. Values are means \pm SD in 2 experiments; ${ }^{*} P<0.05$, Student's $t$-test.

Intact splenocytes were treated in vitro with both substances. Neither CN•Ly nor Ly showed significant effects directly on cells. In the presence of mitogens, only CN•Ly at a concentration of $20 \mu \mathrm{g} / \mathrm{ml}$ significantly enhanced LPS-induced proliferative (fig 2).

\section{Influence on IL-1 production}

Serum IL-1 activity of mice treated with $\mathrm{CN} \cdot \mathrm{Ly}$ was doubled in comparison to the control animals, while Ly had no effect (fig 3). Elevated IL-1 production was detected in the supernatants from pMo, cultured in vitro with CN•Ly and the higher dose (20 $\mu \mathrm{g} / \mathrm{ml})$ showed greater effect. In the case of cultivation with Ly only, the lower concentration of $10 \mu \mathrm{g} / \mathrm{ml}$ exhibited stimulatory action, while a concentration of $20 \mu \mathrm{g} / \mathrm{ml}$ was without effect. As the substances might be present in macrophage supernatants, thymic cells were cultured in RPMI medium containing 10 and $20 \mu \mathrm{g} / \mathrm{ml}$ of CN.Ly or Ly. The complex caused proliferation of thymocytes in a dose-dependent manner, while Ly showed greater effect in a concentration of $10 \mu \mathrm{g} / \mathrm{ml}$, than at a concentration of $20 \mu \mathrm{g} / \mathrm{ml}$. The effect was weaker compared to that of the relevant macrophage supernatants (fig 4).

\section{IL-2 production}

The proliferation of CTLL-2 cells was significantly enhanced when they were cultivated in the presence of supernatants from 


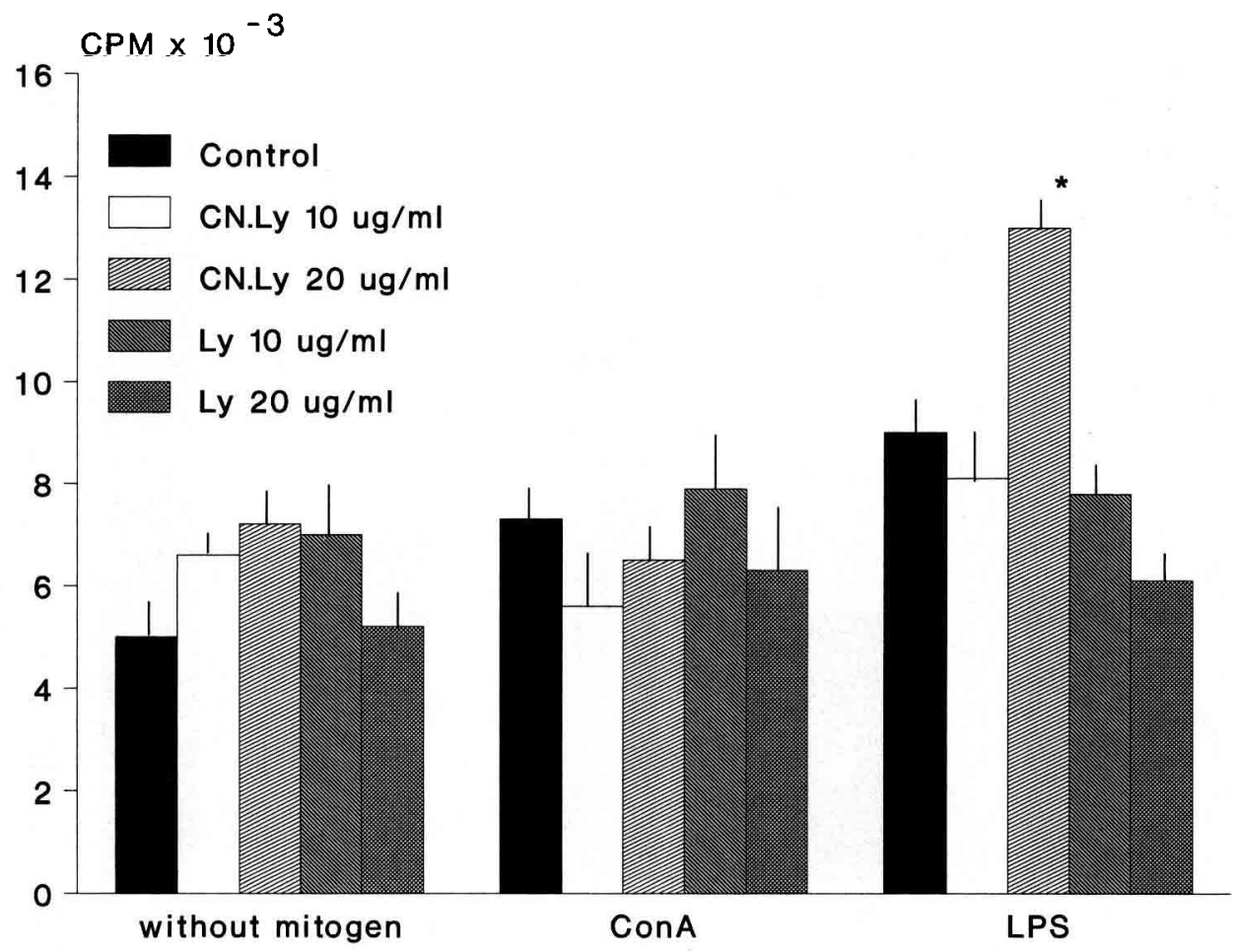

Fig 2. Proliferation of mouse splenocytes, cultivated in vitro with CN•Ly or Ly in the absence of mitogen or in the presence of ConA $(5 \mu \mathrm{g} / \mathrm{ml})$ or LPS $(5 \mu \mathrm{g} / \mathrm{ml})$. Means \pm SD from 3 determinations; ${ }^{*} P<$ 0.01 , Student's $t$-test. Control; $\square \mathrm{CN}$.Ly $10 \mu \mathrm{g} / \mathrm{ml} ;$ CN.Ly $20 \mu \mathrm{g} / \mathrm{ml} ; \mathbf{S L y} 10 \mu \mathrm{g} / \mathrm{ml} ; \mathrm{Ly} 20 \mu \mathrm{g} / \mathrm{ml}$.

splenocytes obtained from animals pretreated with Ly with a maximum on the 2nd day. The complex did not exhibit such activity (fig 5).

\section{DISCUSSION}

Phenolic acids are among the propolis constituents claimed to be responsible for its biological activity (Metzner et al, 1975; Grunberger et al, 1988). Cinnamic acid is reported to possess antibacterial activity (Ikeno et al, 1991) but like most of the phenolic compounds, it exhibits poor solubility and needs high concentrations of organic solvents, such as Tween-80 or dimethylsulfoxide, which make it inconvenient for many biological assays. It was established that phenolic complex isolated from propolis binds basic amino acids ( $\mathrm{L}$-lysine and L-arginine) and forms a water-soluble complex (Nikolov et al, 1987). From a chemical point of view the noncovalent bounds between the phenolics and amino acid easily dissociate. Although the stability of the complex is not defined and the effect of free and bound lysine should be expected to differ, a lysine solution has been used to estimate its possible action. The time needed for CN-Ly to be metabolized is not known, so the amino acid was taken in concentrations approximate to that in the complex. The present results demonstrated that splenic cells from animals pre- 


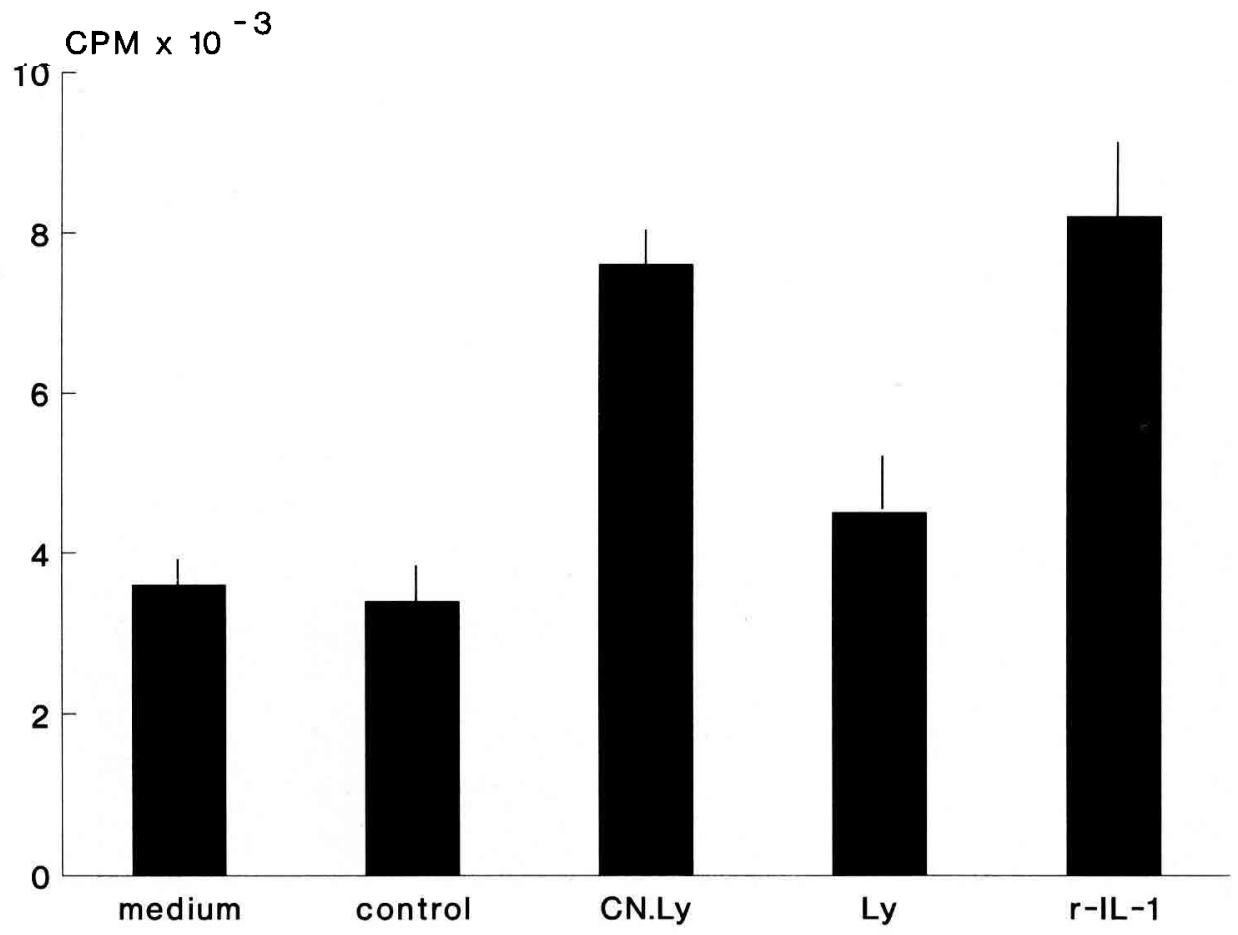

Fig 3. Serum IL-1 activity of treated with CN-Ly or Ly mice. Mouse thymocytes were cultured in the presence of submitogenic PHA concentration $(1 \mu \mathrm{g} / \mathrm{ml})$; recombinant $\mathrm{IL}-1$ at a concentration of $1 \mathrm{ng} / \mathrm{ml}$ as taken as a positive control. Values are means \pm SD from 2 experiments.

treated with $\mathrm{CN} \cdot \mathrm{Ly}$ or Ly had an enhanced mitogen response. It should be noted that cells from animals pretreated with $\mathrm{CN} \cdot \mathrm{Ly}$ were more sensitive to LPS action while cells from mice pretreated with Ly reacted more powerfully to PHA or ConA. In vitro only the LPS-induced proliferation of splenocytes was elevated by the higher CN•Ly concentration of $20 \mu \mathrm{g} / \mathrm{ml}$. These results support the hypothesis that $\mathrm{CN} \cdot \mathrm{Ly}$ and Ly affected different lymphocyte clones.

Thymic lymphocytes treated in vitro with $\mathrm{CN} \cdot \mathrm{Ly}$ or Ly were also triggered to proliferation in the presence of submitogenic PHA concentrations. The high Ly concentration showed a lesser effect in the case of splenic cells.
The fact that splenic cells obtained from animals pretreated with the substances exhibited higher proliferative ability than if the cells from intact animals were treated in vitro with $\mathrm{CN} \cdot \mathrm{Ly}$, indicated that the action of substances was augmented by some immune mediators. The IL-1 assay showed that serum from $C N \cdot L y$-treated animals exhibited increased IL-1 activity, while the effect of Ly was negligible. The results suggest that the CN-Ly directly activated pMo, as the supernatants from in vitro-treated pMo expressed dose-dependent enhancement of IL-1 activity. They also agree with our previous data about the increase in number and total protein secretion of pMo from animals pretreated with CN॰Ly (Ivanovska et 


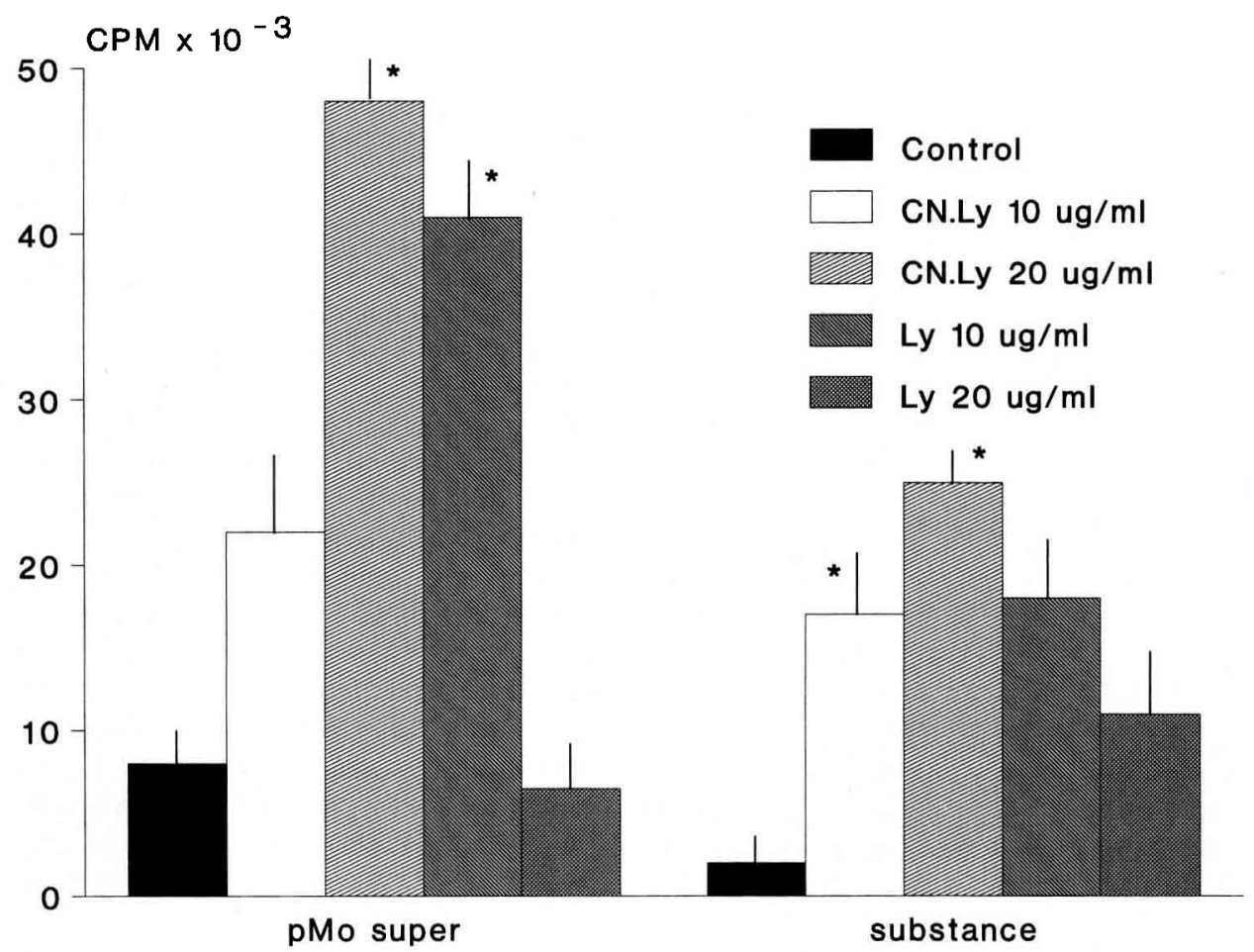

Fig 4. Proliferation of mouse thymocytes cultivated in the presence of supernatants (1:4) obtained from pMo treated in vitro with $\mathrm{CN} \bullet$ Ly or Ly. Substance: thymocytes cultivated in RPMI, containing the appropriate concentrations of $\mathrm{CN} \bullet$ Ly or Ly. Values are means $\pm \mathrm{SD}$ from 3 determinations; ${ }^{*} P<0.05$, Student's $t$-test. Control; $\square$ CN.ly $10 \mu \mathrm{g} / \mathrm{ml} ;$ CN.Ly $20 \mu \mathrm{g} / \mathrm{ml} ; \mathrm{Ly} 10 \mu \mathrm{g} / \mathrm{ml} ;$ Ly $20 \mu \mathrm{g} / \mathrm{ml}$.

al, 1993). The complex activated macrophages, thus affecting the initial phase of the event needs for the immune response. A high level of IL-2 (with maximum on the 2nd day) was detected in the supernatants from splenocytes after in vivo treatment with Ly, while CN•Ly had no effect. Possibly, unbound lysine could occupy some of the lymphocyte receptors which rendered more cells responsive to mitogens or antigens. However, high Ly concentrations might cause a negative effect, which would be a possible explanation for the aggravated effect in $K$ pneumoniae infection after Ly treatment and the lack of effect after application of higher CN-Ly dose. The Ly possibly played a role of a carrier in the com- plex, thus ensuring the transfer of the phenolic into the cells. Further investigations are needed to elucidate the metabolic pathway of the complex, in view of the possible activity of free lysine, which in some cases might be dramatically different, depending on its concentration. In conclusion, the present observations indicate that under certain conditions one of the propolis constituents, cinnamic acid, augments host-defence response through increase of lymphocyte proliferation and induction of cytokine release. These findings provide a basis for obtaining a synthetic preparation with a defined content and desired properties. The addition of lysine is necessary to improve the solubility of compounds. 


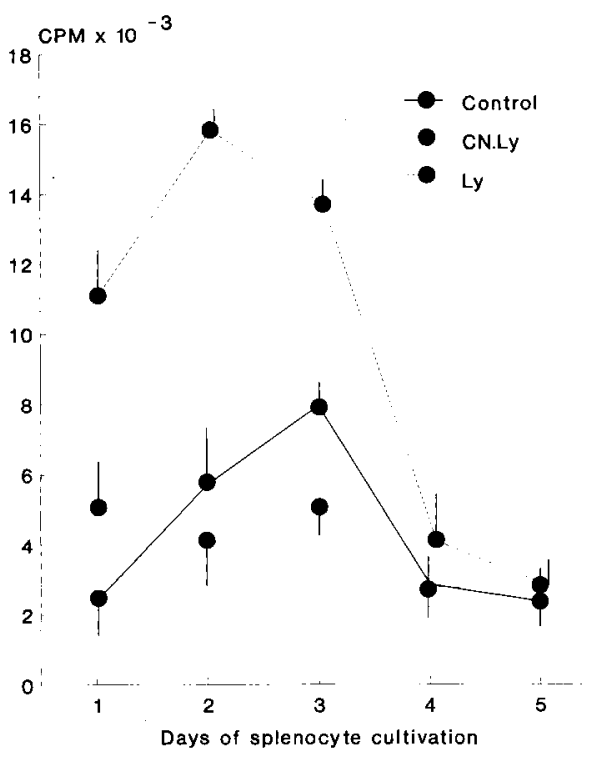

Fig 5. The IL-2 secretion in the supernatants of splenocytes, collected from pretreated with $\mathrm{CN} \cdot \mathrm{Ly}$ or Ly mice and cultivated in the presence of SRBC. Values are means \pm SD of 3 determinations.

\section{ACKNOWLEDGMENTS}

This work was supported by grant X-254 of the National Foundation for Scientific Research (Bulgaria). We thank N Dimitrova for the skillful technical assistance.

Résumé - Influence de l'acide cinnamique sur la prolifération des lymphocytes, la libération de cytokine et l'infection à Klebsiella chez la souris. La présente étude porte sur la capacité de l'un des constituants de la propolis, l'acide cinnamique, combiné avec la L-lysine, à exercer une action sur certains mécanismes immunitaires. Dans tous les tests on a utilisé comme témoin une solution de L-lysine (Ly) à la même concentration que dans le complexe testé. Les substances ont été administrées à des souris par voie intrapérito- nale à la dose de $3 \mathrm{mg} / \mathrm{kg} / \mathrm{j}$ pour le complexe acide cinnamique-L-lysine (CN-Ly) et $2 \mathrm{mg} / \mathrm{kg} / \mathrm{j}$ pour la Ly durant $3 \mathrm{j}$ consécutifs. Vingt-quatre $h$ après le dernier traitement on a prélevé les sérums, les splénocytes et les macrophages péritonéaux ( $\mathrm{pMo}$ ) ou inoculé des cellules de Klebsiella pneumoniae. L'évolution de l'infection a été améliorée par le complexe CN-Ly : le nombre de souris survivantes et le temps moyen de survie étaient élevés de façon significative (tableau 1). Les splénocytes des souris traitées au $C N \cdot L y$ ou à la Ly avaient une capacité accrue à proliférer en présence de concentrations mitogéniques de lipopolysaccharides (LPS), de phytohémagglutinine (PHA) ou de concanavaline A (ConA) (fig 1). In vitro les substances n'ont pas présenté une telle action (fig 2). Le taux d'interleukine-1 était augmenté dans le sérum des souris traités au CN-Ly (fig 3 ) et dans les surnageants des pMo cultivés in vitro avec le complexe (fig 4). Une augmentation de l'activité IL-2 a été détectée dans les surnageants des splénocytes des souris traitées à la Llysine (fig 5). Les résultats laissent supposer que l'acide cinnamique agit directement sur le pMo, alors que sur les lymphocytes son effet interfère avec celui de la lysine. En conclusion, nos observations montrent que dans certaines conditions l'un des composés de la propolis, l'acide cinnamique, accroît la défense de l'hôte par une augmentation de la prolifération des lymphocytes et la libération de cytokine.

\section{propolis / acide cinnamique / infection à Klebsiella / libération cytokine}

\section{Zusammenfassung - Der Einfluß der Zimtsäure auf die Vermehrung der Lym- phozyten, die Cytokinausschüttung und die Klebsiella-Infektion bei Mäusen. In dieser Studie wurde der Einfluß eines Pro- polis-Bestandteils, der Zimtsäure (Cn), kom- biniert mit L-Lysine, auf einige Mechanis- men des Immunsystems untersucht. In allen}


Versuchen wurde eine L-Lysin-Lösung von derselben Konzentration wie in dem CnKomplex als Kontrolle verwendet. Die Substanzen wurden in die Bauchhöhle (ip) der Mäuse in einer Dosis von $3 \mathrm{mg}$ Cn-LysinKomplex pro $\mathrm{kg} / \mathrm{Tag}$ injiziert, und Lysin allein mit $2 \mathrm{mg}$ pro $\mathrm{kg} / \mathrm{Tag}$, und zwar an drei aufeinanderfolgenden Tagen. 24 Stunden nach der letzten Behandlung wurden Serum, Milzzellen und peritoneale Makrophagen (pMo) entnommen, oder es wurde eine Inokulation mit Klebsiella pneumoniae vorgenommen. Der Verlauf der Infektion wurde durch Cn-Ly günstig beeinflußt: Die Überlebensrate stieg an und die Überlebenszeit wurde erhöht (Tabelle I). Milzzellen von mit Cn-Ly oder Ly vorbehandelten Mäusen vermehrten sich stärker in Gegenwart mitogener Konzentrationen von Lipopolysacchariden (LPS), Phytohemagglutinin (PHA) oder Concanavalin A (con A) (Abb 1). In vitro zeigten diese Substanzen aber nicht denselben Effekt (Abb 2). Die Menge von Interleukin-1 (IL-1) war im Serum von Mäusen, behandelt mit $\mathrm{Cn}-\mathrm{Ly}$, erhöht (Abb 3), ebenso im Überstand von pMo-in vitro Kulturen, die mit dem Komplex versetzt waren (Abb 4). Im Überstand von zentrifugierten MilzzelIen von Tieren, die mit Ly vorbehandelt waren, wurde eine gesteigerte Interleukin-2 (IL-2) Aktivität gefunden (Abb 5). Diese Resultate lassen vermuten, daß Zimtsäure auf die peritonealen Makrophagen direkt wirkt, während bei den Lymphozyten eine Wechselwirkung mit Ly eintritt. Zusammenfassend ergibt sich aus den vorliegenden Versuchen der Hinweis, daß die Zimtsäure, ein Bestandteil des Propolis, unter gewissen Bedingungen die Abwehr des Wirtes durch Vermehrung der Lymphozyten und Auslösung einer Cytokin-Ausschüttung erhöht.

\section{Propolis / Zimtsäure / Cytokin-Freiset- zung / Klebsiella Infektion}

\section{REFERENCES}

Bankova V, Dyulgerov A, Popov S, Marekov N (1987) A GC/MS study of the propolis phenolic constituents. Z Naturforsch 42C, 147-151

Dimov V, Ivanovska N, Bankova V, Popov S (1992) Immunomodulatory action of propolis. IV. Prophylactic activity against Gram-negative infections and adjuvant effect of the water-soluble derivative. Vaccine 12, 817-823

Gillis S, Ferm MM, Ou W, Smith KA (1978) T cell growth factor: parameters of production and a quantitative microassay for activity. $J$ Immunol 129, 2027-2034

Greenaway W, May J, Scaysbrook T, Whatley F (1991) Identification by gas-chromatograhy mass-spectrometry of 150 compounds in propolis. $Z$ Naturforsch 46C, 111-121

Grunberger D, Banerjee, Eisinger $\mathrm{K}$ et al (1988) Preferential cytotoxicity of tumor cells by caffeic acid phenethyl ester isolated from propolis. Experientia 44, 230-232

Ikeno K, Ikeno T, Miyazawa C (1991) Effects of propolis on dental caries in rats. Caries Res 25, 347-351

Ivanovska N, Stefanova Z, Valeva V, Dimov V, Bankova $V$, Popov $S$ (1993) Immunomodulatory action of lysine derivatives of cinnamic acid. In: Immunotherapy of Infections (KN Masihi, ed) Marcel Dekker Inc, New York, USA, 177-182

Meltzer MS, Oppenheim JJ (1977) Bidirectional amplification of macrophage-lymphocytes activation factor production by activated adherent mouse peritoneal celis. J Immuno/ 118, 77-82

Metzner J, Bekemeier H, Schneidewind E, Schwaiberger R (1975) Bioautographische Erfassung der antimicrobiell wirksamen Inhaltstoffe von Propolis. Pharmazie $30,799-800$

Nikolov N, Marekov N, Bankova V, Popov S, Ignatova R, Vladimirova I (1987) Method for the preparation of after-soluble derivative of propolis. Bull Pat Appl 79903/28, 05

Walker P, Crane E (1987) Constituents of propolis. Apidologie 18, 327-334 